6. Allen H.D., Thong I.G., Clifton-Bligh P., Holmes S., Nery L., Wilson K.B. Effects of high-dose inhaled corticosteroids on bone metabolism in prepubertal children with asthma. Pediatr Pulmonol. 2000; P. 88-93.

7. Harris M., Hauser S., Nguyen T.V., Kelly P.J., Rodda C., Morton J., Freezer N., Strauss B.J., Eisman J.A., Walker J.L. Bone mineral density in prepubertal asthmatics receiving corticosteroid treatment. J. Paediatr Child Health. 2001; 37:67-71.

8. Van Staa T.P., Bishop N., Leufkens H.G., Cooper C. Are inhaled corticosteroids associated with an increased risk of fracture in children? Osteoporos Int. 2004; P. 85-91.

DOI https://doi.org/10.30525/978-9934-588-81-5-1.30

\title{
ВИЗНАЧЕННЯ ЕФЕКТИВНОСТІ ЛОКАЛЬНОЇ ДІЇ ПЕРЕПАРАТУ НА ОСНОВІ БЕНЗИДАМІНУ ГІДРОХЛОРИД \\ У ПІСЛЯОПЕРАЦІЙНОМУ ПЕРІОДІ У ПАЦІЕНТІВ З ХРОНІЧНИМИ ДЕСТРУКТИВНИМИ ПЕРІАПІКАЛЬНИМИ ПРОЦЕСАМИ
}

\begin{abstract}
Корніснко М. М.
кандидат медичних наук,

асистент кафедри хірургічної стоматологї та щелепно-лицевої хірургії Львівський національний медичний університет імені Данила Галищького

Мінько Л. Ю.

кандидат медичних наук, доцент, доцент кафедри терапевтичної стоматології факультету післядипломної освіти

Львівський національний медичний університет імені Данила Галицького м. Львів, Україна

Проблема профілактики ускладнень залежить від тактики післяопераційного лікування, яка незважаючи на успіхи в ії розробці, вимагає певних вдосконалень. Дані літератури вказують, що навіть найбільш ефективні сучасні фармакологічні препарати та схеми лікування втрачають свій вплив та потребують заміни і вдосконалення $[1,2,3,4,5]$.

Внаслідок операційної травми виникає порушення кровообігу у післяопераційних тканинах, змінюються біохімічні показники ротової
\end{abstract}


рідини, відбувається активація процесу перекисного окислення ліпідів (ПОЛ), що у свою чергу ускладнює й затягує перебіг післяопераційного періоду.

Пошкоджуючому впливу вільних радикалів, які постійно утворюються в організмі, протидіє багатоступенева антиоксидантна система захисту. Однією із ії складових є ферментативна ланка, представником якої є каталаза (КА) - фермент, що розкладає перекис водню, утворюваний у процесі біологічного окиснення, на воду та молекулярний кисень.

Так як, головна функція каталази це руйнування токсичного перекису водню, що утворюється в ході різних окислювальних процесів в організмі, метою досліджень було вияснити різницю іiї активності в ротовій рідині хворих з хронічними деструктивними періапікальними процесами для визначення ефективності локальної дії препарату на основі бензидаміну гідрохлорид в післяопераційному періоді. Оскільки, даний препарат має лікарську форму розпилювачів-спреїв, його зручно використовувати у післяопераційному періоді $[6,7]$.

Порівнюючи отримані дані, спостерігається певна відмінність у динаміці показника активності КА. У хворих групи порівняння $(\mathrm{n}=25)$ спостерігалося поступове зростання цієї величини від $26 \%$ $(\mathrm{p}<0,05)$ на 1 -у добу до $34 \%(\mathrm{p}<0,05)$ над рівнем норми на 3 -ю, що було максимальним у весь час післяопераційного періоду лікування. Надалі величина активності цього ферменту поступово зменшувалася, проте постійно достовірно переважала показник норми на 29\% $(\mathrm{p}<0,05)$ на 5-у добу та $12 \%(\mathrm{p}<0,05)$ на 7-му добу спостереження.

У хворих основної групи ( $\mathrm{n}=25)$, яким було призначено використання препарату на основі бензидаміну гідрохлорид, максимальна активація антиоксидантної ферментативної діяльності виявлена вже у 1-й добі дослідження, а іiі приріст дорівнював $56 \%(\mathrm{p}<0,05)$ до показника норми. У всі наступні терміни відмічалося досить стрімке зменшення активності КА: на 3-ю добу вона ще достовірно переважала показник норми на $35 \%(\mathrm{p}<0,05)$, на 5-у - практично дорівнювала iii значенню, а на 7-у добу виявлено падіння на $21 \%(\mathrm{p}<0,05)$ відносно рівня норми.

Результати свідчать, що місцеве лікування препаратом на основі бензидаміну гідрохлоорид дозволяє зменшити рівень ПОЛ у пошкоджених тканинах, відповідно, зменшити навантаження на систему антиоксидантного захисту та уникнути iї перенавантаження. Внаслідок цього вдається добитися фізіологічного балансу вже на 5-у добу після хірургічного лікування. 


\title{
Література:
}

1. Гаврильців С. Т. Цитокіновий статус у хворих із різним типом запальної реакції при нагноєнні радикулярних кіст нижньої щелепи. Клінічна стоматологія. 2013. № 3-4. С. 92-93.

2. Кузняк Н. Б. Хірургічне лікування радикулярних кіст з використанням біокомпозиційних матеріалів. Клінічна стоматологія. 2014. № 3. C. 19-22.

3. Changes in quality of life following third molar. African Health Sciences. 2011. Vol. 11(3). P. 265-268.

4. Guerrero M. E. Can preoperative imaging help to predict postoperative outcome after wisdom tooth removal? A randomized controlled trial using panoramic radiography versus cone-beam CT. Clinical oral investigations. 2013. Vol. 8. P. 264-268.

5. Halpern L. R. Does prophylactic administration of systemic antibiotics prevent postoperative inflammatory complications after third molar surgery? Journal of Oral and Maxillofacial Surgery. 2007. Vol. 65 (2). P. 177-185.

6. Тимофеев А. А. Использование препарата «Гивалекс» после проведения костнопластических операций. Современная стоматология. 2013. № 4. С. 116-121.

7. Кіщук В. В. Сучасна тактика місцевого лікування хворих на гострий фарингіт та загострення хронічного фарингіту. Журн. Вушних, носових і горлових хвороб. 2010. № 5. С. 54-56.

DOI https://doi.org/10.30525/978-9934-588-81-5-1.31

\section{DESTRUCTIVE FORMS OF ACUTE APPENDICITIS IN CHILDREN}

\author{
Korobko Y. Ye. \\ Assistant Lecturer at the Department of Children Surgery \\ National Pirogov Memorial Medical University, Vinnytsia \\ Vinnytsia, Ukraine
}

The aim: to analyze the causes of destructive forms of acute appendicitis based on the study of the characteristics of pathology in children of Vinnytsia region (Ukraine) in the period from 2005 to 2018.

Materials and methods. We made a retrospective analysis of 980 medical records of patients treated at the Vinnytsia Regional Clinical Hospital 